\title{
Isolation and Characterization of an Endogenous C-Terminal Fragment of the $\alpha$-Neo-endorphin/Dynorphin Precursor from Bovine Caudate Nucleus ${ }^{1}$
}

\author{
CHRISTOPHER J. EVANS, ${ }^{\star, 2}$ JACK D. BARCHAS,“ FREDERICK S. ESCH,‡ PETER BÖHLEN,‡ AND \\ ECKARD WEBER*
}

*Nancy Pritzker Laboratory of Behavioral Neurochemistry, Department of Psychiatry and Behavioral Sciences, Stanford University School of Medicine, Stanford, California 94305 and $\neq$ Laboratories for Neuroendocrinology, The Salk Institute for Biological Studies, La Jolla, California 92037

\begin{abstract}
Antibodies have been raised to a synthetic peptide corresponding to the $\mathrm{C}$-terminal 15 -amino acid residues of prodynorphin, the common precursor to the neo-endorphins and dynorphins. The amino acid sequence of the antigen was based on the sequence deduced from mRNA isolated and cloned from porcine hypothalamus (Kakidani, H., Y. Furutani, H. Takahashi, M. Noda, Y. Morimoto, T. Hirose, M. Asai, S. Inayama, S. Nakanishi, and S. Numa (1982) Nature 298: 245248). Using a radioimmunoassay developed from these antibodies we have isolated an endogenous prodynorphin $\mathrm{C}$ fragment from bovine caudate nucleus. The isolated peptide displayed characteristics on gel filtration similar to those of synthetic prodynorphin C-fragment predicted from the porcine mRNA sequence but had low cross-reactivity in the radioimmunoassay. Sequencing and amino acid analysis showed a substitution of serine for asparagine at position 6 in the porcine sequence. Dynorphin B (rimorphin), which is adjacent to prodynorphin $\mathrm{C}$-fragment in the precursor, was isolated from the same extract. Amino acid analysis and elution position on a gel filtration column confirmed its structure as that previously characterized from bovine pituitary extracts. The release of prodynorphin $\mathrm{C}$-fragment and the $\mathrm{C}$ terminus of dynorphin B from the porcine precursor would require cleavage at a single arginine residue. However, a terminal arginine was not present on either of these prodynorphin peptides isolated from bovine caudate. The data would suggest that processing at a single arginine residue results in elimination of the arginine, a feature in common with processing at paired basic residues.
\end{abstract}

The entire primary amino acid sequence of pre-pro-dynorphin (pre-pro-enkephalin B, pre-pro-neo-endorphin/dynorphin) was recently deduced from mRNA isolated from porcine hypothalamus (Kakidani et al., 1982). A number of endogenous opioid peptides

Received July 27, 1984; Revised December 10, 1984; Accepted December 11,1984

${ }^{1}$ This work was supported by National Institute of Drug Abuse Award DA 01207 to J. D. B. and E. W. by Office of Naval Research Award SRO001:N00014-79-C-0796. J. D. B. holds Research Scientist Award MH 24161. E. W. holds a Potamkin-Lerner fellowship in the neurosciences. We wish to thank Mrs. Sue Poage for her assistance in preparing the manuscript.

${ }^{2}$ To whom correspondence should be addressed. are considered products of this precursor including $\alpha$-neo-endorphin (Kangawa et al., 1981), $\beta$-neo-endorphin (Minamino et al., 1981), dynorphin A (Goldstein et al., 1979), dynorphin(1-8) (Minamino et al., 1980; Seizinger et al., 1981; Weber et al., 1982a), dynorphin B (rimorphin) (Fischli et al., 1982; Kilpatrick et al., 1982), and leucineenkephalin (Hughes et al., 1975; Zamir et al., 1984). Paired basic amino acid residues, particularly lysyl-arginine, are prominent cleavage sites for proteolytic enzymes generating the bioactive peptides. However, two of the opioid peptides, dynorphin B and dynorphin(1$8)$, are released by cleavage at single arginine residues. Processing at single arginine residues is not restricted to pre-pro-dynorphirn; such cleavages generate a number of neuroactive peptides in brain including cholecysystokinin(1-8) (Rehfeld, 1981) somatostatin-28 (Goodman et al., 1982), gastrin-releasing peptide(18-27) (Roth et al., 1983), and metorphamide from proenkephalin (Weber et al., 1983).

Dynorphin B is situated close to the C-terminus of prodynorphin (see Fig. 1). Cleavage at a single arginine residue is required to release the $\mathrm{C}$-terminus of dynorphin $\mathrm{B}$. Contingent upon cleavage at this arginine (residue 241 in the porcine precursor) will be release of prodynorphin C-fragment residues 241 to 250 or 242 to 250 , depending on which side of the arginine the enzyme(s) attack(s) Since there are no obvious additional processing signals in prodynorphin C-fragment such as basic residues, or glycosylation sequences, we reasoned that prodynorphin $\mathrm{C}$-fragment should remain intact and hence be a good nonopioid marker for the presence of prodynorphin. Therefore, we developed a radioimmunoasay $(R \mid A)$ for prodynorphin C-fragment and used this assay to purify endogenous prodynorphin C-fragment immunoreactive material from bovine brain caudate nucleus extracts. The purified peptide was characterized by amino acid composition analysis and automated Edman degradation in the gas phase sequenator. In addition, we purified and characterized dynorphin B from bovine caudate nucleus in order to determine the fate of the single arginine residue at the cleavage site.

\section{Materials and Methods}

All synthetic peptides used in this study were obtained from Peninsula Laboratories (San Carlos, CA). Antibodies were raised in New Zealand white rabbits using bovine prodynorphin $C$-fragment decapentapeptide or dynorphin $\mathrm{B}$ conjugated to thyroglobulin by water-soluble carbodi-imide (see Weber et $\mathrm{al} ., 1982 \mathrm{~b}$, for coupling procedure and injection protocol). The resulting antisera were employed for RIA using ${ }^{125}$-labeled peptides as tracer and second antibody for separation (see Weber et al., 1982a, b). The RIA developed for prodynorphin $\mathrm{C}$-fragment had an $\mathrm{IC}_{50}$ of $300 \mathrm{pmol}$ using a final antisera dilution of 1:12,000. The RIA showed equal cross-reactivity of porcine prodynorphin C-fragment and porcine dynorphin $\mathrm{B}(1-29)$ (which contains prodynorphin $\mathrm{C}$-fragment at the $\mathrm{C}$-terminus). The characteristics of the dynorphin B RIA are described in an earlier publication (Cone et al., 1983) 


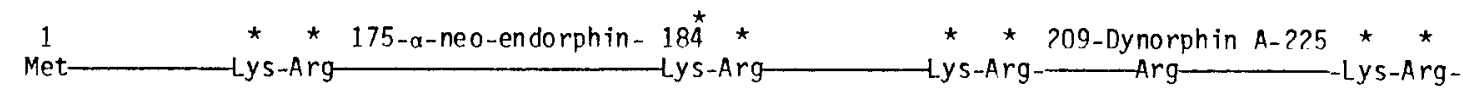

$228 \leftarrow \ldots \ldots$. $242 \leftrightarrow \ldots \ldots \ldots$. Tyr-Gly-Gly-Phe-Leu-Arg-Arg-Gln-Phe-Lys-Val-Val-Thr-Arg-Ser-Gln-Glu-Asp-Pro-Asn-Ala-Tyr-Tyr-Glu-Glu-Leu-Phe-Asp-Val-COOH

Figure 1. Primary sequence of dynorphin $B$ and prodynorphin $\mathrm{C}$-fragment in relation to the structure of porcine neo-endorphin/dynorphin precursor. The asterisks represent known processing sites within the structure.

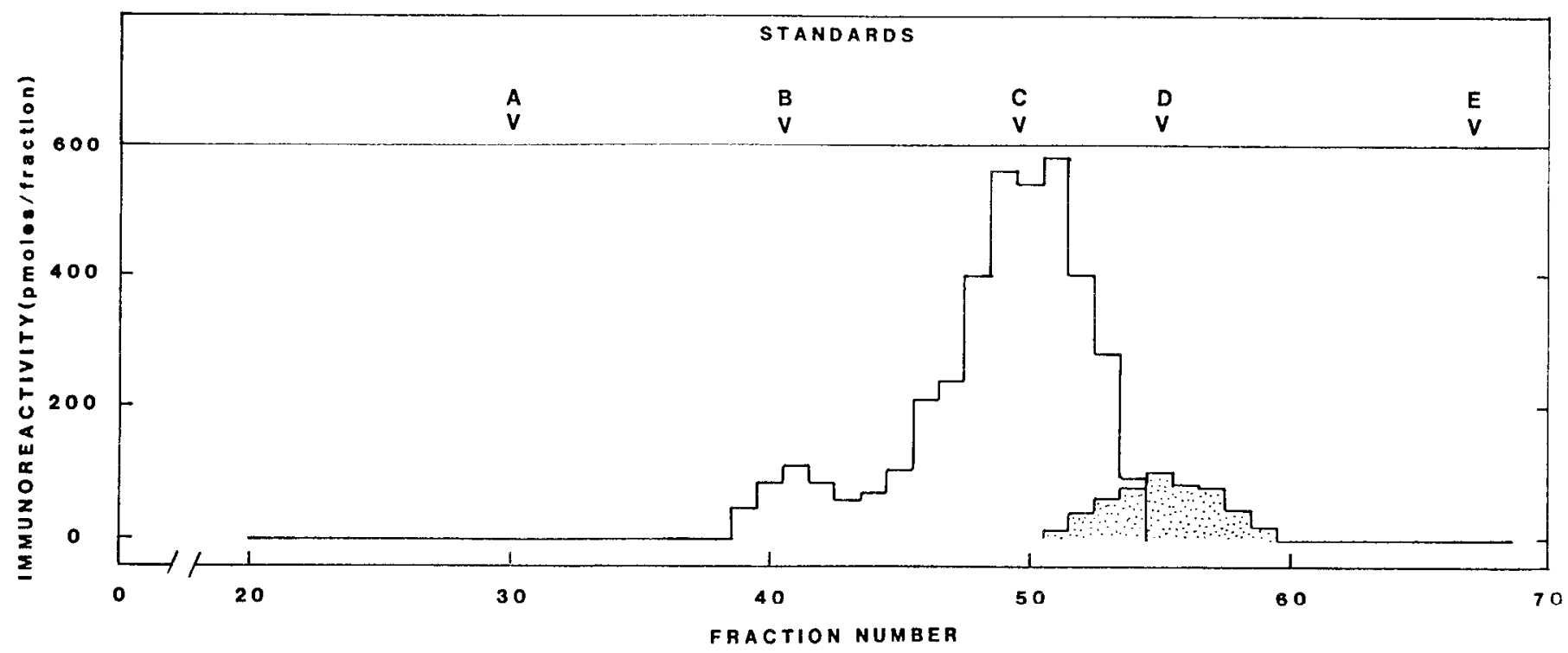

Figure 2. Gel filtration chromatography of an acid/acetone extract of $200 \mathrm{gm}$ of bovine caudate on Sephadex G-50. The dotted histogram represents

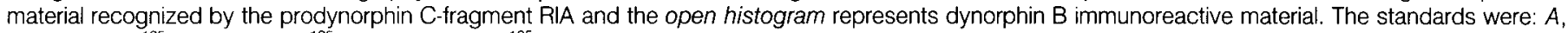
exclusion; $B,{ }^{125}$-lipotropin; $C,{ }^{125}$-dynorphin $B ; D,{ }^{125}$-prodynorphin $C$-fragment; and $E$, salt.

Purification of peptides from bovine caudate nucleus. Bovine caudate nucleus tissue $(\sim 200 \mathrm{gm})$ was obtained from a local slaughterhouse and immediately frozen on dry ice. The tissue was extracted with 1 liter of acetone:water:12 $\mathrm{N} \mathrm{HCl}(40: 6: 1)$ by homogenization in a Waring blender. The homogenate was centrifuged at $15,000 \times g$ for $20 \mathrm{~min}$, and the supernatant was delipidized by heptane extraction ( $\sim 8$ liters). Residual acetone was evaporated from the aqueous layer under a stream of nitrogen for $16 \mathrm{hr}$. The extract was neutralized with ammonia and centrifuged at $15,000 \times g$ for $20 \mathrm{~min}$, and the pellet was discarded. Glacial acetic acid was added to the supernatant to a final concentration of $5 \%$ and precipitated material was removed by centrifugation at $15,000 \times g$ for $20 \mathrm{~min}$. The extract was then loaded onto a $1.9 \times 7 \mathrm{~cm}$ column packed with $40-\mu \mathrm{m}$ reverse phase octadecasilica (ODS) $\mathrm{C} 18$ resin (Altech Associates, Deerfield, IL) prewashed with meth hanol, and equilibrated ir $5 \%$ acelic acid. After washing the column with $50 \mathrm{ml}$ of $5 \%$ acetic acid, the adsorbed peptides were eluted with acetone:water: $12 \mathrm{~N} \mathrm{HCl}(40: 6: 1)$. Immunoreactive eluate was evaporated to dryness by a stream of nitrogen, and the residue was dissolved in $50 \%$ acetic acid and chromatographed on a precalibrated Sephadex G-50 column $(2.5 \times 120 \mathrm{~cm})$ eluted with $50 \%$ acetic acid. Fractions of $5 \mathrm{ml}$ were collected and assayed by RIA for dynorphin B and prodynorphin C-fragment. The immunoreactive peptides were purified by reverse phase high pressure liquid chromotography (RP HPLC) using a $25 \times 0.46 \mathrm{~cm}$ Ultrasphere ODS column, particle size $5 \mu \mathrm{m}$ (Altex, Berkeley, CA).

Three buffer systems were employed for the RP-HPLC. (A) $\mathrm{NaH}_{2} \mathrm{PO}_{4}(50$ $\mathrm{mm}$ ), $5 \%$ methanol adjusted to $\mathrm{pH} 2.7$ with phosphoric acid. The gradient system used with this buffer was 0 to $10 \%$ acetonitrile in $10 \mathrm{~min}$ followed by 10 to $35 \%$ acetonitrile in $175 \mathrm{~min}$. (B) $\mathrm{Na}_{2} \mathrm{HPO}_{4}(100 \mathrm{~mm}), 5 \%$ methanol adjusted to $\mathrm{pH} 7.0$ with phosphoric acid. (see Fig. 3 for acetonitrile gradient). (C) $\mathrm{NaH}_{2} \mathrm{PO}_{4}(50 \mathrm{~mm}), 5 \%$ methanol adjusted to $\mathrm{pH} 7.0$ with triethylamine (acetonitrile gradient identical to that used for system $\mathrm{B}$ ).

As a final purification and desalting step, the peptides were chromatographed on a $7.5 \times 0.46 \mathrm{~cm}$ Ultrasphere ODS column, particle size $3 \mu \mathrm{m}$ (Altex), eluted with an acetonitrile gradient in a $0.1 \%$ trifluoroacetic acid buffer. The RP-HPLC columns were eluted at a flow rate of $1.25 \mathrm{ml} / \mathrm{min}$ for all systems, and fractions were collected over 1-min intervals.

Amino acid analysis following acid hydrolysis and the gas/liquid sequenc- ing techniques have been described in earlier publications (Böhlen and Schroeder, 1982; Esch et al., 1983).

\section{Results}

Figure 2 shows the Sephadex G-50 gel permeation chromatography profiles for dynorphin $B$ and prodynorphin $C$-fragment immunoreactivity following acid/acetone extraction, defatting, and desalting of $200 \mathrm{gm}$ of bovine caudate tissue. Both profiles showed only one prominent peak which co-chromatographed with respective ${ }^{125}$. labeled marker peptide. The prodynorphin C-fragment did not elute at a position that would be predicted from its molecular weight but was considerably retarded on the column, probably due to its highly acidic character. Comparison of the profiles shows that significantly more immunoreactive dynorphin B was detected than prodynorphin C-fragment. For purification, fractions containing prodynorphin $\mathrm{C}$ fragment immunoreactivity were combined, diluted 3-fold with water, and pumped onto a $3 \times 0.45 \mathrm{~cm}$ HPLC precolumn packed with 40 $\mu \mathrm{m}$ reverse phase ODS resin. The precolumn was then connected to the high pressure system and the peptides were chromatographed on the $2.5 \times 0.46 \mathrm{~cm}$ RP-HPLC column using an acid $\mathrm{pH}$ buffer (system A described under "Materials and Methods"). Greater than $80 \%$ of the immunoreactive material eluted in a single peak between 142 and $146 \mathrm{~min}$. This peak was combined and rechromatographed on the same RP-HPLC column at $\mathrm{pH} 7$ (system $\mathrm{B}$ under "Materials and Methods"). Figure 3 shows the immunoreactivity and optical density profile of this purification step. Two peaks were observed, a minor peak containing less than $20 \%$ of the immunoreactive material and a more hydrophobic peak containing the remainder of the immunoreactivity. The major peak was combined and desalted on a 3- $\mu \mathrm{m}$ RP-HPLC column eluted with a steep acetonitrile gradient. Tables I and II show the primary structural analysis of the purified material. The bovine sequence of the $\mathrm{N}$ terminal 14 amino acids differed from the predicted porcine se- 


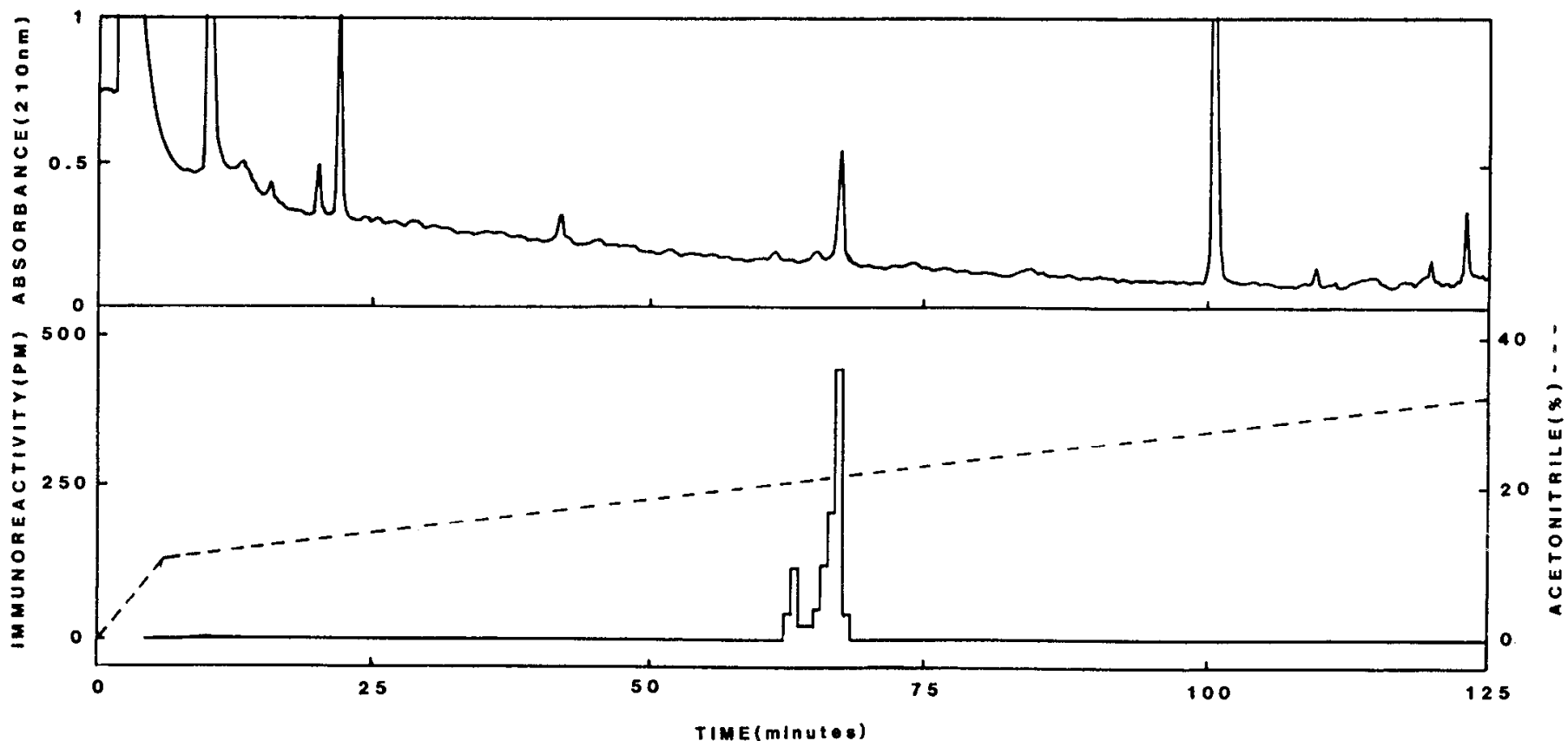

Figure 3. Chromatography of bovine prodynorphin C-fragment on RP-HPLC at pH 7.0 (see "Material and Methods" for details of the buffer system). The upper graph shows the optical density of $210 \mathrm{~nm}$ and the lower graph shows the immunoreactivity profile. The acetonitrile gradient is indicated by the dashed line in the lower graph. Two irmunoreactive peaks were delecled, but only the major, more hydrophobic peak was desalted and analyzed. No immunoreactive material eluted after $75 \mathrm{~min}$.

TABLE ॥

Amino acid analyses data

TABLE I

Primary sequence data of prodynorphin C-fragment from bovine caudate

Bovine prodynorphin C-fragment ( $760 \mathrm{pmol}$ by amino acid analysis) was sequenced on an Applied Biosystems Sequenator using methanolic $\mathrm{HCl}$ for conversions and RP.HPLC for phenylthiohydantoin (PTH) amino acid (AA) identification. The initial yield was $19.8 \%$ and the average repetitive yield was $85.7 \%$. PTH amino acids were detected on 14 cycles. The same sequence was obtained from two consecutive purifications. Note that the sequence starts with a serine residue and differs by only one amino acid (residue ${ }^{6}$ ) from that predicted from the porcine mRNA.

\begin{tabular}{rrrcl}
\hline $\begin{array}{c}\text { Cycle No. } \\
\text { (N) }\end{array}$ & PTH-AA & Yield & $\begin{array}{c}\text { Carryover } \\
\text { from N-1 }\end{array}$ & $\begin{array}{c}\text { Porcine } \\
\text { Sequence AA }\end{array}$ \\
\hline & & \multicolumn{2}{c}{ pmol } & "Arg" \\
& & \multicolumn{3}{c}{ Ser } \\
1 & Ser & 44.5 & 0 & Gin \\
2 & Gin & 52.5 & 1.3 & Glu \\
3 & Glu & 116.6 & 20.8 & Asp \\
4 & Asp & 102.5 & 42.0 & Pro \\
5 & Pro & 91.0 & 61.4 & Asn \\
6 & Ser & 38.0 & 32.9 & Ala \\
7 & Ala & 66.0 & 6.0 & Tyr \\
8 & Tyr & 45.1 & 38.2 & Tyr \\
9 & Tyr & 72.1 & & Glu \\
10 & Glu & 32.8 & 45.5 & Glu \\
11 & Glu & 45.9 & & Leu \\
12 & Leu & 20.5 & 55.3 & Phe \\
13 & Phe & 26.8 & 0 & Asp \\
14 & Asp & 10.7 & 13.6 & Val \\
\hline 15 & & & & \\
\hline
\end{tabular}

Samples were acid hydrolyzed in $6 \mathrm{~N} \mathrm{HCl}$ for $35 \mathrm{hr}$ and then analyzed by ion exchange chromatography with postcolumn o-pthalaidehyde detection. The amino acid analysis for prodynorphin C-fragment agrees with the sequencing data (Fig. 4). The amino acid analysis for dynorphin B was very similar to that previously reported (Kilpatrick et al., 1982), the low Val being explained by a Val-Val in the primary sequence that is not readily acid hydrolyzed.

\begin{tabular}{|c|c|c|c|c|c|}
\hline \multirow{2}{*}{$\begin{array}{l}\text { Amino } \\
\text { Acid }\end{array}$} & \multicolumn{2}{|c|}{$\begin{array}{l}\text { Prodynorphin } \\
\text { C-Fragment } \\
\text { Immunoreactive } \\
\text { Material }\end{array}$} & \multirow{2}{*}{$\begin{array}{l}\text { Predicted } \\
\text { (porcine } \\
\text { sequence) }\end{array}$} & \multicolumn{2}{|c|}{$\begin{array}{c}\text { Dynorphin B } \\
\text { Immunoreactive Material }\end{array}$} \\
\hline & Actual & $\begin{array}{l}\text { Predicted } \\
\text { (sequencing) }\end{array}$ & & Actual & $\begin{array}{l}\text { Predicted } \\
\text { (porcine } \\
\text { sequence) }\end{array}$ \\
\hline Asx & 2.10 & 2 & 3 & 0.18 & \\
\hline Thr & $\leq 0.05$ & & & 1.00 & 1 \\
\hline Ser & 1.68 & 2 & 1 & 0.40 & \\
\hline Glx & 3.99 & 4 & 4 & 1.06 & 1 \\
\hline Gly & 0.11 & & & 2.07 & 2 \\
\hline Ala & 1.01 & 1 & 1 & 0.28 & \\
\hline Val & 1.02 & & 1 & 1.22 & 2 \\
\hline Met & $\leq 0.05$ & & & $\leq 0.05$ & \\
\hline lle & $\leq 0.05$ & & & $\leq 0.05$ & \\
\hline Leu & 1.03 & 1 & 1 & 1.08 & 1 \\
\hline Tyr & 2.00 & 2 & 2 & 0.92 & 1 \\
\hline Phe & 1.00 & 1 & 1 & 1.70 & 2 \\
\hline His & $\leq 0.05$ & & & $\leq 0.05$ & \\
\hline Trp & $\leq 0.05$ & & & $\leq 0.05$ & \\
\hline Lys & 0.06 & & & 1.19 & 1 \\
\hline Arg & $\leq 0.05$ & & & 1.90 & 2 \\
\hline Pro & $N A^{a}$ & 1 & 1 & NA & \\
\hline
\end{tabular}

${ }^{a} \mathrm{NA}$, proline was not analyzed in this experiment. 


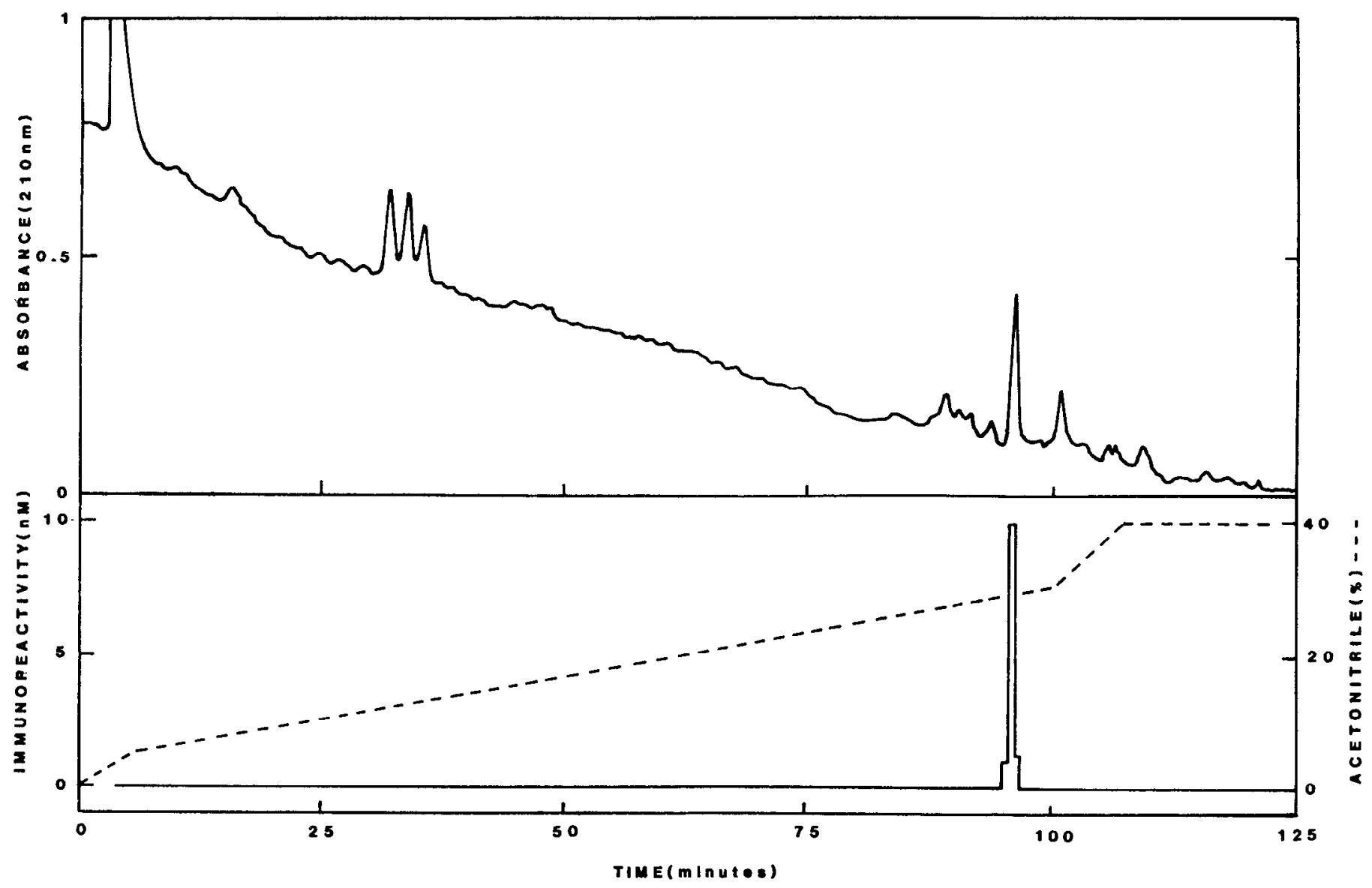

Figure 4. Final purification step of dynorphin B on RP-HPLC in $0.1 \%$ trifluoroacetic acid. The major optical density peak (upper drawing) corresponds to the single immunoreactive peak (lower graph). The acetonitrile gradient is illustrated by the dashed line in the lower graph.

quence by only one residue, a serine at position 6 as opposed to an asparagine. The amino acid analysis was consistent with the sequencing data (Table II). The valine residue detected in the amino acid analysis but not the sequencing presumably corresponded to the C-terminal amino acid of bovine prodynorphin C-fragment, which is also a valine in the porcine sequence. It is typical that hydrophobic $\mathrm{C}$-terminal amino acids are not detected in gas/liquid Sequenator.

For the dynorphin B purification the immunoreactive peak from the Sephadex G-50 column was combined and chromatographed on the $5-\mu \mathrm{m}$ RP-HPLC column at $\mathrm{pH} 7.0$ (system $\mathrm{C}$ described under "Materials and Methods"). The immunoreactivity eluted in a single symmetrical peak. Tubes containing immunoreactive material were combined and desalted on the 3- $\mu \mathrm{m}$ RP-HPLC column (see Fig. 4). Amino acid analysis of the purified dynorphin B (Table II) showed two arginine residues in the peptide indicating that dynorphin $B$ did not retain a third (C-terminal) arginine in its structure (see Fig. 1).

\section{Discussion}

The elucidation of the entire sequence of pre-pro-dynorphin from the mRNA enables the analysis of precursor protein fragments not recognized by bioassays or RIAs directed to the biologically active fragments. Important information on the location and processing of the precursor can be deduced from studying these fragments. In this regard, prodynorphin C-fragment is particularly relevant since it is generated from prodynorphin by cleavage at a single arginine residue. Furthermore, this peptide is at the C-terminus of the precursor and consequently should be a good marker peptide for the precursor. In this study we have raised antisera to prodynorphin $\mathrm{C}$ fragment and isolated and characterized the endogenous immuno reactive material from bovine caudate that reacted with the antisera. The isolated peptide had only one amino acid change from the porcine sequence, that of a serine residue for an asparagine at position 6.

This single amino acid change resulted in the bovine sequence having less than $15 \%$ cross-reactivity in the RIA as calculated by comparison with the amino acid analysis quantities. In this regard it should be noted that, in the Sephadex G50 profile (-ig. 1), considerably more immunoreactive dynorphin $B$ was detected than prodynorphin C-fragment. However, when the profiles are corrected for cross-reactivity with the bovine structures, the values are approximately equal. The adjusted values show that the prodynorphin $\mathrm{C}$ fragment is a major metabolite of prodynorphin in bovine caudate and consequently may make an excellent marker for this precursor in other tissues.

With regard to prodynorphin C-fragment in other species, no immunoreactive material could be detected in rat or guinea pig brain extracts (unpublished observation). Whether the sequence of rodent prodynorphin $\mathrm{C}$-fragment is very different from the porcine counterpart or deleted from the precursor remains to be determined.

The high degree of conservation between the porcine and bovine sequences in the C-terminal region of prodynorphin would strongly predict retention of the single arginine cleavage site between dynorphin B and prodynorphin C-fragment. The structural analysis of dynorphin $\mathrm{B}$ and prodynorphin $\mathrm{C}$-fragment from bovine caudate demonstrates that neither cleavage product possesses a terminal arginine residue. There are a number of conceivable enzymic mechanisms that could lead to the observed products. A probable mechanism would be a combination of a trypsin-like activity followed by carboxypeptidase B-like hydrolysis of the C-terminal arginine. This scheme would be analogous to that proposed for cleavage at double basic amino acid residues (Steiner et al., 1974). However, there is no direct experimental evidence supporting this concept, 
and enzymes specifically cleaving on the amino side of arginine have been described in adrenal glands (Mizuno et al., 1982).

We anticipate that this and similar studies will provide useful information on the specificity of the enzyme(s) that generate neuroactive peptides via cleavages at single arginine residues.

\section{References}

Böhlen, P., and R. Schroeder (1982) High sensitivity amino acid analysisMethodology for the determination of amino-acid compositions with less than 100 pmoles of peptides. Anal. Biochem. 126:; 144-152.

Cone, R., E. Weber, J. D. Barchas, and A. Goldstein (1983) Regional distribution of dynorphin and neo-endorphin peptides in rat brain, spinal cord, and pituitary. J. Neurosci. 3: 2146-2152.

Esch, F. S., P. Böhlen, N. C. Ling, P. E. Brazeau, W. B. Wehrenberg, and R. Guillemin (1983) Primary structures of three human pancreas peptides with growth hormone-releasing activity. J. Biol. Chem. 258: 1806-1812.

Fischli, W., A. Goldstein, M. Hunkapiller, and L. Hood (1982) Isolation and amino acid sequence analysis of a 4,000-dalton dynorphin from porcine pituitary. Proc. Natl. Acad. Sci. U. S. A. 79: 5435-5437.

Goldstein, A., S. Tachibana, L. I. Lowney, M. Hunkapillar, and L. Hood (1979) Dynorphin-(1-13), an extraordinarily potent opioid peptide. Proc. Natl. Acad. Sci. U. S. A. 76: 6666-6670.

Goodman, R. H., J. W. Jacobs, P. C. Dee, and J. F. Habener (1982) Somatostatin-28 encoded in a cloned CDNA obtained from a rat medullarythyroid carcinoma. J. Biol. Chem. 257: 1156-1159.

Hughes, J., L. W. Smith, H. W. Kosterlitz, L. A. Fothergill, B. A. Morgan, and H. R. Morris (1975) Identification of 2 related pentapeptides from brain with potent opiate agonist activity. Nature 258: 577-579.

Kakidani, H., Y. Furutani, H. Takahashi, M. Noda, Y. Morimoto, T. Hirose, M. Asai, S. Inayama, S. Nakanishi, and S. Numa (1982) Cloning and sequence analysis of cDNA for porcine $\beta$-neo-endorphin/dynorphin precursor. Nature 298: $245-248$.

Kangawa, K., H. Minamino, N. Chino, S. Sakakibara, and H. Matsuo (1981) The complete amino acid sequence of $\alpha$-neo-endorphin. Biochem. Biophys. Res. Commun. 99: 871-877.

Kilpatrick, D. L., A. Wahlstrom, H. W. Lahm, R. Blacher, and S. Udenfriend
(1982) Rimorphin, a unique, naturally occurring [Leu]enkephalin-containing peptide found in association with dynorphin and $\alpha$-neo-endorphin. Proc. Natl. Acad. Sci. U. S. A. 79: 6480-6483.

Minamino, N., K. Kangawa, A. Fukuda, H. Matsuo, and M. Igarashi (1980) A new opioid octapeptide related to dynorphin from porcine hypothalamus. Biochem. Biophys. Res. Commun. 95: 1475-1481.

Minamino, N., K. Kangawa, N. Chino, S. Sakaibara, and H. Matsuo (1981) $\beta$ Neo-endorphin, a new hypothalamic "big" leu-enkephalin of porcine origine: Its purification and complete amino acid sequence. Biochem. Biophys. Res. Commun. 99: 864-870.

Mizuno, K., A. Miyata, K. Kangawa, and H. Matsuo (1982) A unique proenkephalin-converting enzyme purified from bovine adrenal chromaffin granules. Biochem. Biophys. Res. Commun. 108: 1235-1242.

Rehfeld, J. F. (1981) Four basic characteristics of the gastrin cholecystokinin system. Am. J. Physiol. 240: 6255-6266.

Roth, K. A., C. J. Evans, R. G. Lorenz, E. Weber, J. D. Barchas, and J. -K. Chang (1983) Identification of gastrin releasing peptide-related substances in guinea pig and rat brain. Biochem. Biophys. Res. Commun. 112: 528536

Seizinger, B., V. Hollt, and A. Herz (1981) Evidence for the occurrence of the opioid octapeptide dynorphin-(1-8) in the neurointermediate pituitary of rats. Biochem. Biophys. Res. Commun. 102: 197-205.

Steiner, D. F., W. Kemmler, H. S. Tager, and J. D. Paterson (1974) Proteolytic processing in biosynthesis of insulin and other proteins. Fed. Proc. 33: 2105-2114.

Weber, E., F. S. Esch, P. Böhlen, S. Paterson, A. D. Corbett, A. T. McKnight, H. W. Kosterlitz, J. D. Barchas, and C. J. Evans (1983) Metorphamide: Isolation, structure and biologic aclivity of a novel amidated opioid octapeptide from bovine brain. Proc. Natl. Acad. Sci. U. S. A. 80: 7362-7366.

Weber, E., C. J. Evans, and J. D. Barchas (1982a) Opioid peptide dynorphin: predominance of the aminoterminal octapeptide fragment in rat brain regions. Nature (Lond) 299: 77-79.

Weber, E., C. J. Evans, J. K. Chang, and J. D. Barchas (1982b) Antibodies specific for $\alpha-N$-acetyl- $\beta$-endorphin: Radioimmunoassays and detection of acetylated $\beta$-endorphins in pituitary extracts. J. Neurochem. 38: 436-447.

Zamir, N., M. Palkovits, E. Weber, E. Mezey, and M. J. Brownstein (1984) A dynorphinergic pathway of leu-enkephalin production in the rat substantia nigra. Nature 307: 643-645. 